\title{
With a Little Help from my Friends: Multinational Retailers and China's Consumer Market penetration
}

Charlotte Emlinger \& Sandra Poncet

\section{Highlights}

- The expansion of western hypermarkets induces a relative rise in imports for retailer goods.

- This rise is greater for import flows originating from the retailers' headquarters countries.

- Our results suggest that a $20 \%$ higher multinational retailer presence, amounting to one additional hypermarket in 2012, induces a relative rise in imports in retail goods of $2.8 \%$ compared to non retail goods. The import relative gains rise to $5.6 \%$ for the multinational retailers' headquarters countries.

- The observed effect is consistent with the appeal of Western gastronomy and with the structuring role of retail branded products. 


\section{Abstract}

We study the growing presence of multinational retailers and its role for imports in China. To identify the causal effect of foreign retailers entry on the local import intensity, we use sector and origin country level import data for a panel of Chinese cities between 1997 and 2012 and differentiate between retailer and non retailer goods, and, in a second step, we exploit information on the multinational retailers' headquarters countries. We find that a relative rise in retail imports in cities where multinational retailers settle, which is sharper for imports from the country of origin of the retailer. Our results suggest that a $20 \%$ higher multinational retailer presence, amounting to one additional hypermarket in 2012, induces a relative rise in imports in retail goods of $2.8 \%$ compared to non retail goods. The import relative gains rise to $5.6 \%$ for the multinational retailers' headquarters countries. We find that the observed effect is mainly driven by the food products, which is consistent with the appeal of Western gastronomy and with the structuring role of retail branded products. Our results suggest that global retailers bridgehead for the penetration of the Chinese market by producers from their home base.

\section{Keywords}

Multinational retailers, China, Imports.

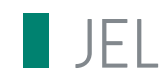

L81, F14, F23.

\section{Working Paper}

\section{CEPI}

CEPII (Centre d'Etudes Prospectives et $d^{\prime}$ 'Informations Internationales) is a French institute dedicated to producing independent, policyoriented economic research helpful to understand the international economic environment and challenges in the areas of trade policy, competitiveness, macroeconomics, international finance and growth.
CEPII Working Paper

Contributing to research in international economics

(c) CEPII, PARIS, 2016

All rights reserved. Opinions expressed in this publication are those of the author(s) alone.

\begin{tabular}{|c|c|}
\hline Editorial Director: & CEPII \\
\hline Sébastien Jean & $\begin{array}{l}\text { 113, rue de Grenelle } \\
75007 \text { Paris }\end{array}$ \\
\hline $\begin{array}{l}\text { Production: } \\
\text { Laure Boivin }\end{array}$ & +33153685500 \\
\hline No ISSN: $1293-2574$ & www.cepii.fr \\
\hline
\end{tabular}




\title{
With a Little Help from My Friends: multinational retailers and China's consumer market penetration
}

\author{
Charlotte Emlinger* and Sandra Poncet ${ }^{\dagger}$
}

\section{Introduction}

China is in the midst of an economic makeover to rebalance its economy through the increase of domestic private consumption. Consumption is replacing investment as China's main engine of economic growth, creating significant opportunities in the retail market. China has overtaken the United States to become the world's biggest market for grocery shopping in 2011. Penetrating the highly profitable and rapidly growing Chinese retail market is even more now the key objective for most western producers and retailers.

Multinational hypermarkets established only recently in China but developed very quickly. The number of foreign grocery retailers outlets in the Chinese market went from zero in 1995 to 126 in 2000 and reached 2,516 in 2014 (Planet Retail, 2014). The extent to which this expansion has helped producers from the home base of the retailers to penetrate the Chinese consumer market is however unclear. Indeed, foreign retailers in China mainly propose locally-sourced products: 90 and 95\% of the products offered in Carrefour and Walmart's Chinese stores respectively are produced in China (Moreau, 2008). In contrast to the well-studied case of Mexico, foreign retailers in China do not bring with them a significant imports from their home base (Durand, 2007).

This paper investigates the extent to which foreign global retailers can nevertheless act as bridgehead for the penetration of the Chinese market by their home exporters. Our empirical analysis relies on sector-country level import data for 287 cities over the 19972012 period. ${ }^{1}$ We consider the 5 leading foreign grocery retailers in China -Auchan, Carrefour, Metro, Tesco and Walmart- and use a difference-in-differences specification. Our identification exploits variations in the expected impact of the multinational retailers presence between retailer and non-retailer goods to isolate the causal effect on imports. We furthermore investigate whether the international global retailers presence in Chinese cities has resulted in a disproportional rise in the imports from the country of origin of the retailers.

This paper fits in the emerging literature on the economic implications of overseas expansion of multinational retailers in the home and host countries. Most of the existing literature focuses on the impact of the global retailer store operations on host countries'

\footnotetext{
${ }^{*}$ Corresponding author: CEPII, E-mail: charlotte.emlinger@cepii.fr

${ }^{\dagger}$ Paris School of Economics (University of Paris 1) and CEPII, E-mail: sandra.poncet@univ-paris1.fr.

${ }^{1}$ China is divided into 4 municipalities (Beijing, Tianjin, Shanghai and Chongqing) and 27 provinces which are further divided into prefectures. As is common in the literature, we use the terms city and prefecture interchangeably, even though prefectures include both an urban and a rural part.
} 
economic performance. A first effect is local firm productivity enhancement. Global retail chains' entry has been shown to fuel productivity improvements by supplier firms in Romania (Javorcik and Li, 2013) and in Mexico (lacovone et al., 2015; Javorcik et al., 2008). A second channel of retailer influence on the host economy is exports. There is evidence that increased exposure to multinational retailers raises exports by enhancing the general export capabilities of the location (Head et al., 2014). In contrast, this paper investigates whether the presence of multinational retailers affects host location imports. Our work searches for additional ways for retailer influence to shape international trade. More specifically a subset of our results takes the perspective of the home countries of the multinational retailers and asks whether the international expansion of their retailers contributes to their export competitiveness.

Our paper relates to the studies measuring the importance of imports for retailers (Raff and Schmitt, 2015). Evidence based on direct import activities by retailers in the US stresses that bigger retail firms tend to import more and that retailers are especially active in importing low-value products, predominantly from China (Bernard et al., 2010). Basker and Van (2010b) go beyond direct imports and identify a positive link between the growth of large retailers and that of imports of consumer goods across US sectors. ${ }^{2}$ They show that the largest retail chains have a much higher propensity than smaller retailers to import from less-developed countries, first and foremost China and that their larger sourcing of cheap (durable and semi-durable) products especially from China make these large chain retailers dominate local retail markets. Our focus is different since we look at western retailers' presence in China, the country from which hypermarkets typically source a large share of the non-food products. In the specific context of China, the opening of western hypermarkets hence is less likely to result in higher imports of non-food consumer products which would be displayed on its shelves. China is hence a very good setting to identify more indirect channels through which the presence of multinational retailers contributes to the international opening of the domestic consumer market.

Our work hence contributes to the recent empirical evidence of a positive effect of a country's retailers overseas presence on its exports to those markets. Cheptea et al. (2015a) use bilateral exports for a large panel of countries over the 2000-2010 decade and find that higher sales of a retailer in a country is associated with larger imports by that country from the home base of the retailer. Two broad mechanisms can be at play. First, the establishment or extension of operations abroad by a retailer from a given country reduces the export costs of the home base firms exporting to these markets. Indeed multinational retailers may continue to work with their domestic suppliers in their international operations. Also, their foreign activities may generate informational externalities that benefit to the home base exporters. Second, multinational retailers may influence consumer demands and give rise to new consumption behaviors. More generally, they can improve the global image of their home country among the population that they serve and generate a higher demand from goods (not only retailer ones) originating from their home.

Departing from an international panel and focusing on a single country like China seems

\footnotetext{
${ }^{2}$ Because their import data is only at the product level, they need to make several challenging assumptions to map imports to retail sub-sectors.
} 
relevant for several reasons. First, the country's opening to multinational retail chains is recent, so our analysis covers the emergence from scratch of the now largest retail market in the world. Second, using cross-regional data within a single country instead of crosscountry data mitigates data compatibility problems which are typical in cross-country regressions. Third, the large size of the country and the differences of entry timing of multinational retailers across cities provide substantial variations that our empirical approach will exploit so as to extract the causal effect on imports of the presence of multinational retailers.

Our analysis builds on recent efforts to address the problem of endogenous location of multinational retailers. It is indeed likely that the timing and specific location choice of foreign hypermarkets opening in China are correlated with various broader economic variables as well as specific ties with the origin country of the retailers which likely affect import propensity. Foreign retailers clearly opened their first stores in well-developed regions, such as the Eastern metropolis of Shanghai, the busy port of Shenzhen or the capital Beijing. Another problem comes from reverse causality: greater trade openness affects the structure of the retail industry. Two recent theoretical models suggest that trade liberalization is associated with greater market concentration in retailing, hence that large scale and cost effective chain retailers should expand (Basker and Van, 2010a; Raff and Schmitt, 2012). We then risk over-estimating the positive import effects of hypermarkets opening.

Our main strategy to counter endogeneity exploits variations in the expected impact of the global retail chains opening by product categories and by the imports' origin. We hence consider the differences in the speed of expansion of the 5 leading foreign grocery retailers across 287 cities and the fact that retailer goods should be more affected by the hypermarkets presence. This setting allows us to include city-year fixed effects, hence to account for all the reasons behind the fastest development of retail markets in one location in a year.

Our main findings are a relative rise in imports following the development of the top 5 multinational retailer activities in China. The magnitude of the effect is economically meaningful: a $10 \%$ increase in the number of these western retailer stores in a city induces a relative rise in retail products imports of $1.9 \%$.

The second part of our analysis exploits information on the imports' country origin. We find that the multinational retailers presence in Chinese cities has resulted in a disproportional rise in the imports from the country of origin of the retailers. This is in line with Cheptea et al.'s (2015a) results and suggests that a retailer expansion triggers various transaction cost reducing effects that benefit specifically to its home base producers. Our results are robust to a variety of checks including the inclusion of city-country-year fixed effects and accounting for the development of Asian retailer chains. As a falsification test, we re-estimate our model with processing imports which consist of inputs to be processed in China before re-exporting. None of the estimated international store coefficients are significant, suggesting that our findings do not simply reflect a general surge in retail imports in the cities chosen by the multinational retailers.

Our attempt to uncover the mechanisms at play behind the import-enhancing effect con- 
sists of two parts. First, we differentiate the relative rise in retailer goods imports between food and non-food products. We find that the observed effect is mainly driven by the food products. This is consistent with the role of long-lasting and trustful relationships between retailers and home base food producers as well as with the importance of retail branded products in food. Most multinational retailers are engaged in own brand strategy. Retail branded products are supplied by firms that have to comply with private standards defined by retail companies and certified through a private independent organism. For example, Carrefour, Auchan and Metro use the IFS (International Food Standard) certification to ensure the quality and safety of the products for which they have the legal responsibility. This tight contractual relationship between retailers and suppliers may imply that those bilateral links persists throughout the internationalization process of retail companies.

Second we subsequently allow the overall effect to differ across the top- 5 retailers under investigation. These 5 retailers differ in terms of the relative role of retail branded products. The appeal of the national food products is also different, inducing a heterogeneous capacity of retailers to shape local consumption habits. We find greater effects for UKbased and France-based retailers which is consistent with the reputation of the agrifood sector of these two countries.

Overall, our results show that global retailers appear to bridgehead for the penetration of the Chinese market by home base producers.

The remainder of the paper is structured as follows. Section 2 describes the developments of multinational retailer activity in China and presents our measure of retailer presence in Chinese cities based on the top 5 multinational retailers. Section 3 describes the import data and the empirical specification relating import intensity and multinational retailers' presence. Section 4 presents the results of the regression linking multinational retailers presence and imports. Last, Section 5 concludes.

\section{Multinational retailer activity in China}

\subsection{China's opening to multinational retailers}

The western retailers actually expanded in China after 1995 following the deregulation of retailing in China (Wang and Zhang, 2006). China's retail market opening was gradual and imposed restrictions which forced the multinational retailers to choose different entry locations. Up to 1995, only 11 designated zones ${ }^{3}$ could welcome operations by foreign retailers, with a maximum of two per zone (Head et al., 2014). These restrictions also concerned retailers emanating from Greater China, i.e. Hong Kong, Macao and Taiwan. As a result western retailers were induced to have different strategies to locate their first hypermarket in mainland China. Our analysis takes advantage of the uneven exposure of Chinese cities to the activities of multinational retailers due to these spatial differences of timing and extent.

As detailed in Table A-2, France-based Carrefour (the second largest world retailer and first in the EU market) stepped in first in 1995 with an hypermarket in Beijing. American

\footnotetext{
${ }^{3}$ They include 6 cities (Beijing, Shanghai, Tianjin, Guanzhou, Dalian, and Qingdao) and 5 Special Economics Zones (Shenzhen, Zhuhai, Shantou, Xiamen and Hainan).
} 
Walmart (the world's largest retailer) and German Metro followed the next year with hypermarkets respectively in Shenzhen and Shanghai. The UK-based Tesco entered in 1998 while the French Auchan arrived in 1999, both settling in Shanghai.

Table A-2 reports the main characteristics of the western retailers. It lists the year and location of entry in China and gives indicators related to sales and store numbers to assess their relative presence in Chine. In 2010, Auchan and Carrefour account respectively for 13.3 and $10.4 \%$ of the Chinese grocery retail sales made in hypermarkets. Walmart comes third with $10.4 \%$ followed by Metro and Tesco each with 3.5\% (Planet Retail, 2014). These market shares are significant even in comparison with those of Chinese retailers. Two Chinese retailers stand out: the China Resources group (Vanguard hypermarkets) and the Linhua company (Century Mart, Lianhua and Hualian brands). They accounted respectively for 26 and $22 \%$ of the 2010 grocery sales made in hypermarkets in China (Retail planet, 2014).

\subsection{Retailers' store distribution}

The yearly store distribution across China for each of the five multinational retailers was collected from various websites. The two main sources are the retailers' websites and the Chinese web site linkshop. ${ }^{4}$ We measure retailers's presence as the hypermarket store count for each retailer in a location. ${ }^{5}$

Figure A-1 illustrates that the timing and extent of multinational retailers' local presence vary across Chinese cities. Comparison of the situation in 1997 and 2012 stresses the rapid growth in the number of stores established by the top 5 multinational retailers in China. In 1997, the beginning year in our sample, the retailer activities were very limited and concentrated in few, mostly coastal, cities. By 2012, the end year in our sample, the number of hypermarkets had expanded to 858 including inland locations.

In robustness checks we account for the retail activity of some major Asian chains. We use the web site linkshop to compute the store count of Japan-based Aeon, Korea-base E-mart and Lotte-Mart, Taiwan-based RT-mart and Thailand-based Lotus.

\section{Empirics}

\subsection{Import flows}

We use Chinese customs data from 1997 to 2012. China's import flows are reported by foreign country of origin and destination city in China. Chinese customs regulations require importers to report the place of consumption of their imports which may differ from the port of entry of the location of the importing firm. We use the 4-digit (prefecture-level city) location information. We observe import flows by detailed product classification (Harmonized System 6-digit) and by trade regime (ordinary or processing trade). ${ }^{6}$ Our

\footnotetext{
${ }^{4}$ The Chinese website http://www. Iinkshop.com.cn/focuses on the retail industry.

${ }^{5}$ Following the literature we only consider the big-box retail format that sells the widest range of retail goods and omit the specialty and convenience stores as they differ in product coverage and have much smaller sales areas (Head et al., 2014).

${ }^{6}$ Operations in the processing sector involve importing inputs to process them in China and re-export the final products.
} 
analysis relies on the fact that only retailer goods imports under the ordinary regime should be affected by the chains' presence. Our baseline results hence exclude processing activities. We re-estimate our main specifications with processing imports as a falsification test and find no significant effect of multinational retailers presence on the local relative import intensity of processing activities.

We use the Broad Economic Categories (BEC) classification of goods to identify the products that represent retailer goods. These include food products for household consumption, corresponding to primary and processed food and beverage (categories 111 and 112) and non food-products, corresponding to semi-durable and non-durable consumer goods (categories 62 and 63). Our dataset is constructed to differentiate between three categories of products for bilateral imports by a Chinese city from a country of a HS2 sector. The first two categories include products offered in the big-box retail format of multinational retailers (food and non-food products). The third category includes nonretailer goods and constitutes the control group in our regressions. ${ }^{7}$ We hence aggregate HS6 products into categories by HS2 to generate a panel of city-product-country-year observations where products refer to a given category at the HS2 level. We obtain a nomenclature of 159 products across 97 HS2 chapters.

\subsection{Empirical specification}

Our empirical analysis assesses whether a greater presence of multinational retailers boosts local imports. Specifically, we study whether differences in retailer good relative import growth across Chinese cities are linked to the uneven geographical expansion of global retailers within China. To identify the causal import effect of multinational retailer presence, we use sector and destination country level import data for a panel of Chinese cities and rely on the fact that only retailer goods imports should be affected by the chains' presence. In a second step, we furthermore exploit information on the multinational retailers' headquarters countries so that our identification exploits variations in the expected impact of the multinational retailers presence both by products and by countries of origin of the imports.

We estimate the following equation on our panel of product-level bilateral import data for 287 cities over 1997-2012:

$$
\text { In Imports } \text { Ipct }=\beta \text { Western Retail Stores }_{i t} \times \text { Retail }_{p}+\lambda_{i p c}+\mu_{p c t}+\nu_{i c t}+\epsilon_{i p c t}
$$

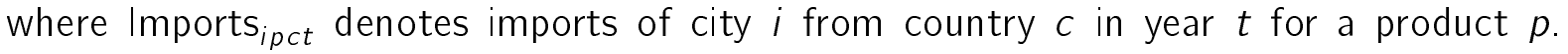
Our sample contains 159 products, defined as categories (non-retailer goods, retailer food goods and retailers non-food goods) within an HS2. Our explanatory variable of interest is $\ln \left(1+n_{i t}\right)$, where $n_{i t}$ is the count of hypermarkets established in city $i$ by the 5 top global retailers -Auchan, Carrefour, Metro, Tesco and Walmart. It is denoted Western Retail Stores ${ }_{i t}$. We focus on the interaction term of this measure and the dummy for the retailer goods denoted as Retail ${ }_{p}$. The latter is equal to one for food and non-food retailer goods within HS2 chapters.

\footnotetext{
${ }^{7}$ In 1997 , retail goods constitute $2.5 \%$ of imports by the 287 cities in our sample. This proportion rises to $3.2 \%$ in 2012 .
} 
Our specification includes city-product-country fixed effects, $\lambda_{i p c}$, to account for specialization patterns at the bilateral level. A city may have a natural inclination to import specific goods from a given international source due to historical factors or the presence of immigrants from that partner. Product-country-year fixed effects, $\mu_{p c t}$, are further introduced to capture country-level variations in the supply of goods to the Chinese market over time. They account for shocks that are common to all cities related to international links between China and its partners whether they are product specific (tariffs) or not (exchange rates movements).

We further control for time-varying city-specific factors by including a set of city-year fixed effects. They take into account the uneven economic development and retail market regulations across Chinese cities and control for any shocks to market conditions in a given location that affect the demand of all products in the city equally. Most importantly, they eliminate any simultaneity bias that might arise due to endogenous location of multinational chains. In our baseline specification, we allow for city-year dummies varying by origin country of imports, $\nu_{i c t}$. Doing so helps to distinguish the impact of foreign retail chains from the general shocks in the bilateral links between a city and a foreign country. For example it helps to ensure that our findings do not solely reflect the repercussions of foreign direct investments in city $i$ from country $c$. Note that if the mere impact of global retailers is to familiarize local consumers to the overall reliability and quality of imported goods or even to promote the specific global image of the home base of the retailers, then this would be picked up in our city-country-year fixed effects. Our specification hence focuses on the differential response of retail products imports.

In presence of those fixed effects our key parameter $\beta$ in the Equation 1 captures whether the growing number of hypermarkets affects the local relative import propensity for retailer goods. To identify whether the import impact is specific to the retailers' home country, we further exploit import origin variations and interact our variable of interest, the interaction term Western Retail Stores ${ }_{i t} \times$ Retail $_{p}$, with a dummy equal to one when imports originate from the headquarter country of the locally established multinational retailers. We also refine our empirical approach to estimate the retailer-specific effects: we include the counts of hypermarkets (and their interaction terms) for the four main countries -France, Germany, UK and US- simultaneously.

In a last attempt to improve the identification of the impact with respect to possible endogeneity concerns, we further add city-product-year fixed effects. We also zoom on the category of products which is the most susceptible to benefit from the expansion of western retailers presence that is food products for household consumption. We further add interaction terms of our multinational retailer presence measure with a dummy for food retailer goods denoted as Food $_{p}$.

We cluster standard errors at the location level to take into account the fact that the measures of retailer chains' presence are specific to cities (though time-varying) and to address potential serial correlation problems (Bertrand et al., 2004). 


\section{Results}

\subsection{Baseline}

Table 1 reports our baseline estimates. In columns 1 and 2, we estimate Equation 1 without the city-country-year fixed effects, $\nu_{i c t}$, so as to assess the overall association between the import intensity of a city and the number of multinational retailers it hosts. Column 2 adds our key interaction term between the western retailers presence and the retailer goods dummy. The coefficients on the proxy for the presence of multinational retailers and on its interaction term with the dummy denoting retailers goods are both positive and significant. This suggests a rise in imports following the expansion of western hypermarkets which is faster for retailer goods. Column 3 further includes fixed effects at the city-year level inducing the number of western retail stores to drop out. The cityyear fixed effects account for time-varying city-level demographic and economic conditions that may relate to city-level imports and also affect the location choice of multinational retailers. Among other these fixed effects absorb possible controls for the local presence of domestic retailer chains.

Compared to column 2, the point estimate of our key parameter $\beta$ on the interaction term between the multinational retailers expansion and the retailer goods dummy is reinforced. It rises from 0.09 to 0.16 although the difference is not statistically significant. Column 4 shows our benchmark specification in Equation 1 with city-country-year fixed effects. Controlling for time-varying bilateral factors that are common to all goods however does not affect the size and significance of $\beta$. The positive and significant $\beta$ is confirmed, suggesting that western retailers expansion did indeed induce a relative rise of imports for goods offered in hypermarkets. A $10 \%$ higher presence of multinational retailers contributed to a $1.9 \%$ relative rise in retailer good local import intensity.

Table 2 proposes several robustness checks. Column 1 excludes imports flows from HongKong, Taiwan and Macao. These Greater China territories, Hong Kong especially, play a specific role in intermediating trade between China and the rest of the world (Feenstra and Hanson, 2004). Part of the imports originating from these well-known "entrepot" and import-export platforms may in fact correspond to re-imported Chinese goods. Exclusion of the 100,000 observations corresponding to imports from these three partners leave our estimates unchanged. Column 2 excludes import flows from countries without global retail chains. Column 3 excludes imports flows from Chinese cities without any foreign hypermarkets (from western or Asian retail companies). Removing these different countries or cities does not change our result.

Column 4 re-estimate our baseline specification with processing imports instead of ordinary imports as a falsification test. We may worry that our measured import-creating effect of multinational retailers reflect unobserved shocks at the level of a city-product-country triad which correlate with both imports and the location choice of multinational retailers. While these shocks should apply to processing as well as ordinary activities, no import gains should emanate from the greater presence of foreign hypermarkets on processing activities, i.e. imports of goods to process them in China prior to re-exporting. None of the estimated western retail stores coefficients are significant to explain processing imports, suggesting that our findings do not simply reflect a general relative retail import rise in 
the cities were the multinational retailers settle.

\subsection{Bilateral effects}

So far our results suggest that multinational retailer presence elevates the local relative propensity to import retailer goods. We expect this rise to be greater for import flows originating from the retailers' headquarters countries for several reasons. First, the presence of hypermarkets from their country of origin may reduce trade costs for exporters, by decreasing market prospecting costs and by lowering informational and logistical costs. Second, the exporters of the retailers' country of origin may benefit from a change in the consumers' preferences in the city where the multinational retailer operates. Third, multinational retailers may have privileged links with their home suppliers and continue to work with them in their international operations.

In this subsection, we investigate the potential heterogeneous effect of retailer chains presence at the city level on imports from the specific countries where the multinational retailers are headquartered. Table 3 exploits information on the multinational retailers' headquarters countries to assess whether the measured relative rise in retail imports in cities where multinational retailers settle is sharper for imports from the country of origin of the retailer. Hence we test how Chinese imports from France are related to the geographic spread of Carrefour and Auchan in China, and imports from Germany, the United Kingdom and the US are linked in turn to the geographic spread of Metro, Tesco, and Walmart. To do so, we refine Equation 1 and further interact our two key variables Western Retail Stores ${ }_{i t}$ and Western Retail Stores ${ }_{i t} \times$ Retail $_{p}$ with a dummy equal to one if the studied import flow originates from the headquarter country of a locally-established hypermarket. Hence if Metro and Carrefour are both present in city $i$ the dummy Home ${ }_{c}$ takes the value of 1 for import flows from France and from Germany.

Column 1 of Table 3 reports the results adding Western Retail Stores ${ }_{i t} \times$ Home $_{c}$ and Western Retail Stores ${ }_{i t} \times$ Retail $_{p} \times$ Home $_{c}$ interaction terms to the specification of column 3 of Table 1 . The former term fails to be significant while the triple interaction term attracts a positive and significant coefficient, suggesting that the relative rise in retail imports in cities where multinational retailers settle is sharper for imports from the country of origin of the retailer. This result remains unchanged with the inclusion of city-countryyear fixed effects, controlling for all time-varying bilateral factors in Column 2. Our results suggest that a $20 \%$ higher multinational retailer presence, amounting to one additional hypermarket in 2012, induces a relative rise in imports in retail goods of $2.8 \%$ compared to non retail goods. The import relative gains rise to $5.6 \%$ for the multinational retailers' headquarters countries.

Finding that the multinational retailers presence in Chinese cities results in a disproportional rise in the imports from the country of origin of the retailers is in line with Cheptea et al.'s (2015a, b) findings that a retailer expansion triggers various transaction cost reducing effects that benefit specifically to its home base producers, particularly retailers' supplying firms. Foreign retailers expansion also generates positive externalities, either informational or reputational for producers in their country of origin. Our results nevertheless suggest that the relative rise in retailer goods imports is not limited to the connections formed by the retailers' bilateral networks. This is consistent with the top 5 retailers familiarizing 
local consumers with imported products and generating a new demand for foreign products going beyond brands from their home base.

Column 3 adds two new variables which help assessing the capacity of retailers to shape local consumption habits. The main difference of retail products displayed on the shelves of the various hypermarket chains has to do with food products. Carrefour and Auchan hypermarkets for example offer a variety of France-produced wines and alcoholic beverages, pastries and dairy products while Tesco proposes UK-manufactured biscuits, crisps, breakfast cereals and curries. One can consequently assume that the impact of retail chain presence on city level import from the country of origin of the retailer is higher for food products. We build on the difference-in-difference approach which previously compares retailer goods to other products non offered in hypermarkets and extend it to investigate

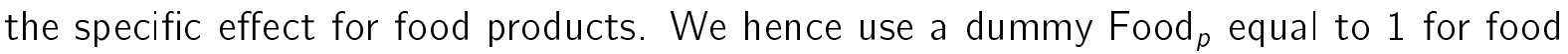
goods and interact it with both the city-level count of western retail stores and its interaction with the $\mathrm{Home}_{c}$ dummy. The coefficient on Western Retail Stores $i c t \times$ Food $_{p}$ fails to be significant suggesting that the import gains from the growing foreign retailers presence is no different for food products than for other non-food retail goods. By contrast the triple interaction term Western Retail Stores ${ }_{i c t} \times$ Food $_{p} \times$ Home $_{c}$ enters with a positive and significant coefficient which is twice larger than the one attracted by the term Western Retail Stores ${ }_{i c t} \times$ Retail $_{p} \times$ Home $_{c}$ in the previous Column 2. This larger magnitude and the fact that the coefficient on Western Retail Stores ${ }_{i c t} \times$ Retail $_{p} \times$ Home $_{c}$ turns insignificant suggests that the previously measured relative retailer import expansion originating from their headquarter country was fully driven by the food segment. This is confirmed and even reinforced in column 4 when adding city-product-year fixed effects. We find robust evidence that increased exposure to international retailers in Chinese cities prompts a relative rise in local retail goods imports, this rise being entirely attributable to foods products, which is consistent with the comparative advantage of the country of origin of the multinational retailers on the Chinese market.

Table 5 performs robustness checks similar to that in Table 2 on the specification of column 2 of Table 3. Table 6 applies the same logic for results further adding the interaction with food products of column 3 of Table 3. Precisely, column 1 excludes import flows from Hong-Kong, Taiwan and Macao as these Greater China origins may play a specific trade platform role. Column 2 excludes import flows from countries without global retail chains to checks that our results on the import gains for links originating from the retailers' headquarters countries are not driven by these countries that are not part of the major global retailers' international store networks. Column 3 excludes cities without foreign (western and Asian) retailers to ensure that the results do not solely emanate from a difference between cities with and without international retailing. Column 4 runs our falsification test based on processing activities as we expect that international chains' expansion should only impact retailer goods imports under the ordinary regime. Our message of an import promoting effect of global retailers which is magnified for food products from their home base is confirmed. Hence while the growing presence of global retailers promotes the local relative propensity to import retailer goods in general, it seems to have the capacity to bridgehead for the penetration of the Chinese market by food producers from their home base.

Table 6 ensures that these findings resist the control for the presence of Asian retailers. 
We use a count of hypermarkets from 5 Asian leading retailers ${ }^{8}$. Column 1 of Table 6 is based on the specification of column 2 of Table 3 . The interaction terms involving Asian retailers presence enters with a positive and significant coefficient, which however does not affect the size and significance of $\beta$. Our results hence suggest an import promoting effect of retailers expansion for Asian chains. However, the coefficient of the triple interaction Asian Retail Stores ${ }_{i c t} \times$ Retail $_{p} \times$ Home $_{c}$ is insignificant, suggesting that the positive impact of Asian retail chain on city level imports is the same whatever the country of origin. Unlike Western chains, Asian chain do not promote imports from their country of origin. Column 2 allows for an heterogenous effect for food products, following the specification of column 3 of Table 3. The coefficient of triple interactive variable for Asia is negative and significant, meaning that the presence of Asian retail chains reduces the relative propensity to import food products from the country where the Asia chain is headquartered. Our main finding on the impact of Western hypermarkets remains. The import promoting impact of retail chains on imports shipped from the retailers' headquarters countries appears to be specific to Western companies.

\subsection{Retailer-specific effects}

In this last subsection, we pursue further the analysis of the impact of Western retail chain presence on city level import by looking at retailer-specific effects. The import promotion effect of retail companies may differ according to the country where the chain is headquartered, due to different product specialization. For example, whereas food products represent $5.5 \%$ of Chinese imports from France, they only amount to $0.7 \%$ of imports from Germany.

Table 7 follows the specification of Table 3, distinguishing the impact of Western hypermarkets on imports by retail chain. Thus, Tesco Stores ${ }_{i t}$, Metro Stores $i t$, Walmart Stores ${ }_{i t}$, Carrefour-Auchan Stores $i t$, are respectively the count of Tesco, Metro, Walmart and Carrefour-Auchan hypermarkets established in city $i$ the year $t .^{9}$. Column 1 and 2 displays results with city-year fixed effect, while the Columns 3 and 4 add city-product-year fixed effects. Column 2 and 4 perform robustness check and exclude flows corresponding to beverage (Chapter 22 of the Harmonized System), as these products represent a high share of Chinese import from Western countries, in particular France (67\%), and to a lesser extent Germany (23\%) and Great Britain (16\%). The impact of retailers presence on imports appears heterogeneous with regards to the retail chain. French retail stores (Carrefour and Auchan) entail a relative rise of import of retail goods, whatever the origin of the good, as shown by the positive coefficient of the interacted variable Carrefour-Auchan Stores ${ }_{i c t} \times$ Retail $_{p}$. Walmart stores have similar and even higher effect on city level import of goods offered in hypermarkets, while Tesco and Metro stores do not have any impact on imports of retail goods. Considering bilateral effects, Carrefour-Auchan Stores $_{i t} \times$ Food $_{p} \times$ Home $_{c}$ and Tesco Stores $i t \times$ Food $_{p} \times$ Home $_{c}$ attracted positive coefficients, suggesting that the import promoting effect of Western retailers for food measured previously emanates from UK and France based retailers. This result is

\footnotetext{
${ }^{8}$ The count includes hypermarkets of Japan-based Aeon, Korea-base E-mart and Lotte-Mart, Taiwan-based RT-mart and Thailand-based Lotus.

${ }^{9}$ Carrefour and Auchan stores impact are count together, as they are both French retail chain and follow the same supply strategy
} 
robust to the exclusion of beverage products and hence is not limited to French Wine or British whiskies.

The significant impact of retail stores on imports from their country of origin for Auchan, Carrefour and Tesco is in line with the appeal of their national food products and with their strategy in terms of product offer. These three chains are engaged for many years in an own-brand strategy and retail branded products represent now an important amount of sales in their hypermarkets, in particular for food products $(43 \%$ for Tesco, $30 \%$ in Carrefour and Auchan stores in average), that is not the case of Metro, who developed only recently (in 2009) its own-brand. To offer own-branded products, retail chains implement contractual relationship with their suppliers and ensure the quality and safety of products through particular private certification labels. Difficulties to find local suppliers able to follow the requirement of these standards may lead retail chains keeping their traditional suppliers to offer their own branded products in their stores around the world (Reardon 2007). The importance of retail branded product has a structural effect on the sourcing strategy of hypermarkets. For example, Cheptea et al. (2015b) show that the benefits of French retail oversea expansion on French agrifood exports are grasped by retailers's domestic suppliers, having retail private certification.

Furthermore, to capitalize on the appeal of French food, Carrefour offers besides the classical Carrefour brand goods more than 200 food products and 40 wines under the label "Reflets de France" on international markets. ${ }^{10}$ These products developed through the long-lasting and trustful relationships between the French retailer and many home base food producers are proposed in China-based Carrefour stores for the Chinese consumers to discover the French gastronomy. Auchan has a similar strategy and also proposes French regional products under the label "Les Produits Régionaux" and some gourmets products beside the basic Auchan home brand goods. Tesco does not have such label, but proposes products with British characteristics, especially those sold under Tesco Finest, the retailer's most premium range of retail brand products. These specificities are likely to induce import flow from France and UK in order to have these typical French and British products in China-based stores. Also, it may improve the reputation of French and British gastronomy that benefits more widely to food products from these countries. For its part, although Walmart also offers a premium retail brand, called Sam's Choice, this covers a large choice of food products with little national gastronomy positioning, that can explain why we find a promoting effect of Walmart hypermarkets for food imports from all origins, but not from US in particular.

\section{Conclusion}

This paper assesses whether multinational retailer expansion facilitates China's consumer market penetration. Exploiting data on the five largest western retailers in China - Auchan, Carrefour, Metro, Tesco and Walmart, we find that imports of retail goods rise in locations as the local number of hypermarkets expands. This relative rise in retail imports in cities where multinational retailers settle is sharper for imports from the country of origin of the

\footnotetext{
${ }^{10}$ Born in 1996 Reflets de France (http://www.refletsdefrance.com/) offer high-quality local products from French regional producers including cheese, charcuterie, canned goods or wines. This label is a retail brand, but products do not carry the retailer name on their packaging.
} 
retailer. The observed effect is mainly driven by the food products, which is consistent with the appeal of Western gastronomy and with the structuring role of retail branded products which entail privileged links of the retailers with their home based traditional suppliers as they expand in China. Our results suggest that global retailers bridgehead for the penetration of the Chinese market by producers from their home base. 


\section{References}

Basker Emek, Shawn Klimek and Pham Hoang Van, 2012, Supersize It: The Growth of Retail Chains and the Rise of the "Big Box" Store, Journal of Economics and Management Strategy, 21 (3), Fall, 541-582

Basker Emek and Pham Hoang Van, 2010a, Imports "R" Us: Retail Chains as Platforms for Developing-Country Imports, American Economic Review (Papers and Proceedings), 100 (2), May, 414-418

Basker Emek, Shawn Klimek and Pham Hoang Van, 2010b, Putting a Smiley Face on the Dragon: Wal-Mart as Catalyst to U.S.-China Trade, revised version of University of Missouri Department of Economics Working Paper 07-10.

Bernard, Andrew, J. Bradford Jensen, Stephen J. Redding, and Peter K. Schott, 2010, Wholesalers and Retailers in U.S. Trade. American Economic Review, 100, 408-13.

Bertrand, Marianne, Duflo, Esther, Mullainathan, Sendhil, 2004, How much should we trust differences-in-differences estimates? Quarterly Journal of Economics, 119 (1), 249-275.

Cheptea, Angela, Charlotte Emlinger and Karine Latouche, 2015a, Multinational Retailers and Home Country Food Exports, American Journal of Agricultural Economics, 97(1):159-179.

Cheptea Angela, Emlinger Charlotte and Latouche Karine, 2015b, Do exporting firms benefits from retail internationalization? Evidence from France. CEPII Working Paper 2015- 21.

Durand Cédric, 2007, Externalities from foreign direct investment in the Mexican retailing sector, Cambridge Journal of Economics, 31 (3), 393-411.

Feenstra, Robert and Gordon Hanson, 2004, Intermediaries in Entrepot Trade: Hong Kong Re-Exports of Chinese Goods, Journal of Economics \& Management Strategy, 1, 3-35.

Head, Keith, Ran Jing and Deborah Swenson, 2014, From Beijing to Bentonville: Do Multinational Retailers Link Markets?, Journal of Development Economics 110, 79-92.

Javorcik Beata and Yue Li, 2013, Do the Biggest Aisles Serve a Brighter Future? Global Retail Chains and Their Implications for Romania, Journal of International Economics, 90 (2), 348-363.

Javorcik, Beata, Keller, Wolfgang and Tybout, James, 2008, Openness and industrial response in a Wal-Mart world: a case study of mexican soaps, detergents and surfactant producers, The World Economy 31 (12),

lacovone Leonardo, Beata Javorcik, Wolfgang Keller and James Tybout, 2015, Supplier Responses to Walmart's Invasion in Mexico, 95 (1), 1-15.

Moreau, Raphael, 2008, Retail in practice, The Retail Digest, March 22, 42-45.

Planet Retail, 2014, China Country Profile. http://www1.planetretail.net/.

Raff, Horst and Nicolas Schmitt, 2012, Imports and the Structure of Retail Markets, Canadian Journal of Economics, 45 (4), 1431-55.

Raff, Horst and Nicolas Schmitt, 2015, Retailing and international trade: A survey of the literature, Economics Working Paper, Christian-Albrechts-University Kiel, Department of Economics 2015-02. 
Wang, Shuguang and Yongchang Zhang, 2006. Penetrating the Great Wall, conquering the Middle Kingdom: Wal-Mart in China. Wal-mart World? The World's Biggest Corporation in the Global Economy. Routledge, Taylor \& Francis Group, New York, NY, pp. 293-313. 
Table 1 - Baseline specification: retailer expansion and imports

\begin{tabular}{|c|c|c|c|c|}
\hline Explained variable & (1) & $\begin{array}{l}\ln \operatorname{Imp} \\
(2)\end{array}$ & $\begin{array}{r}\mathrm{rts}_{i p c t} \\
\text { (3) }\end{array}$ & (4) \\
\hline $\begin{array}{l}\text { Western Retail Stores }_{i t} \\
\text { Western Retail Stores }_{i t} \times \text { Retail }_{p}\end{array}$ & $\begin{array}{l}0.180^{a} \\
(0.043)\end{array}$ & $\begin{array}{c}0.166^{a} \\
(0.046) \\
0.089^{c} \\
(0.049)\end{array}$ & $\begin{array}{c}0.161^{a} \\
(0.056)\end{array}$ & $\begin{array}{c}0.187^{b} \\
(0.072)\end{array}$ \\
\hline $\begin{array}{l}\text { Observations } \\
\text { R-squared }\end{array}$ & $\begin{array}{c}1,154,374 \\
0.784\end{array}$ & $\begin{array}{c}1,154,374 \\
0.784\end{array}$ & $\begin{array}{c}1,154,374 \\
0.791\end{array}$ & $\begin{array}{c}1,154,374 \\
0.822\end{array}$ \\
\hline $\begin{array}{l}\text { City-Product-Country fixed effects } \\
\text { Product-Country-Year fixed effects } \\
\text { City-Year fixed effects } \\
\text { City-Country-Year fixed effects }\end{array}$ & $\begin{array}{l}\text { Yes } \\
\text { Yes } \\
\text { No } \\
\text { No }\end{array}$ & $\begin{array}{l}\text { Yes } \\
\text { Yes } \\
\text { No } \\
\text { No }\end{array}$ & $\begin{array}{l}\text { Yes } \\
\text { Yes } \\
\text { Yes } \\
\text { No }\end{array}$ & $\begin{array}{c}\text { Yes } \\
\text { Yes } \\
- \\
\text { Yes }\end{array}$ \\
\hline
\end{tabular}

Heteroskedasticity-robust standard errors clustered at the city level appear in parentheses. Imports ${ }_{i p c t}$ denotes imports of city $i$ from country $c$ in year $t$ for a product p. Products are defined as categories (non-retailer goods, retailer food goods and retailers non-food goods) within an HS2. ${ }^{a},{ }^{b}$ and ${ }^{c}$ indicate significance at the $1 \%$, $5 \%$ and $10 \%$ confidence levels.

Table 2 - Retailer expansion and imports: robustness checks

\begin{tabular}{||l|ccc|c||}
\hline \hline Explained variable & \multicolumn{4}{|c||}{ In Imports Ipct } \\
& $\begin{array}{c}\text { Excluding Greater } \\
\text { China origins } \\
\text { Sample }\end{array}$ & $\begin{array}{c}\text { Excluding countries } \\
\text { w/o retailers } \\
(1)\end{array}$ & $\begin{array}{c}\text { Excluding cities } \\
\text { w/o retailers } \\
(3)\end{array}$ & $\begin{array}{c}\text { Processing } \\
\text { activities } \\
(4)\end{array}$ \\
\hline \hline Western Retail Stores $_{i t} \times$ Retail $_{p}$ & $0.183^{b}$ & $0.176^{b}$ & $0.187^{b}$ & 0.058 \\
& $(0.074)$ & $(0.074)$ & $(0.072)$ & $(0.059)$ \\
\hline Observations & $1,054,186$ & 999,702 & $1,004,076$ & 363,602 \\
R-squared & 0.825 & 0.822 & 0.820 & 0.844 \\
\hline City-Product-Country fixed effects & Yes & Yes & Yes & Yes \\
Product-Country-Year fixed effects & Yes & Yes & Yes & Yes \\
City-Country-Year fixed effects & Yes & Yes & Yes & Yes \\
\hline \hline
\end{tabular}

Heteroskedasticity-robust standard errors clustered at the city level appear in parentheses. Imports ipct $_{\text {denotes }}$ imports of city $i$ from country $c$ in year $t$ for a product $p$. Products are defined as categories (non-retailer goods, retailer food goods and retailers non-food goods) within an HS2. Column 1 excludes imports flows from Hong-Kong, Taiwan and Macao. Column 2 excludes import flows from countries without global retail chains. Column 3 excludes cities without foreign (western and Asian) retailers. In contrast to our baseline regressions on ordinary trade transactions, in column 4 , imports correspond to processing activities. ${ }^{a},{ }^{b}$ and ${ }^{c}$ indicate significance at the $1 \%, 5 \%$ and $10 \%$ confidence levels. 
Table 3 - Country-specific effect: retailer expansion and imports

\begin{tabular}{|c|c|c|c|c|}
\hline Explained variable & \multicolumn{4}{|c|}{ In Imports Ipct $_{1}$} \\
\hline Western Retail Stores $_{i t} \times$ Home $_{c}$ & $\begin{array}{l}-0.032 \\
(0.030)\end{array}$ & & & \\
\hline Western Retail Stores $_{i t} \times$ Retail $_{p}$ & $\begin{array}{l}0.141^{b} \\
(0.056)\end{array}$ & $\begin{array}{l}0.165^{b} \\
(0.072)\end{array}$ & $\begin{array}{l}0.183^{a} \\
(0.063)\end{array}$ & \\
\hline Western Retail Stores $_{i t} \times$ Retail $_{p} \times$ Home $_{c}$ & $\begin{array}{l}0.138^{b} \\
(0.064)\end{array}$ & $\begin{array}{l}0.138^{b} \\
(0.068)\end{array}$ & $\begin{array}{c}0.095 \\
(0.068)\end{array}$ & $\begin{array}{l}-0.010 \\
(0.070)\end{array}$ \\
\hline Western Retail Stores $_{i t} \times$ Food $_{p}$ & & & $\begin{array}{l}-0.101 \\
(0.121)\end{array}$ & \\
\hline Western Retail Stores $i t \times$ Food $_{p} \times$ Home $_{c}$ & & & $\begin{array}{l}0.244^{c} \\
(0.127)\end{array}$ & $\begin{array}{l}0.332^{b} \\
(0.145)\end{array}$ \\
\hline Observations & $1,154,374$ & $1,154,374$ & $1,154,374$ & $1,154,374$ \\
\hline R-squared & 0.791 & 0.822 & 0.822 & 0.868 \\
\hline City-Product-Country fixed effects & Yes & Yes & Yes & Yes \\
\hline Product-Country-Year fixed effects & Yes & Yes & Yes & Yes \\
\hline City-Year fixed effects & Yes & - & - & - \\
\hline City-Country-Year fixed effects & No & Yes & Yes & Yes \\
\hline City-Product-Year fixed effects & No & No & No & Yes \\
\hline
\end{tabular}

Heteroskedasticity-robust standard errors clustered at the city level appear in parentheses. Imports $_{i p c t}$ denotes imports of city $i$ from country $c$ in year $t$ for a product $p$. Products are defined as categories (non-retailer goods, retailer food goods and retailers non-food goods) within an HS2. ${ }^{a},{ }^{b}$ and ${ }^{c}$ indicate significance at the $1 \%, 5 \%$ and $10 \%$ confidence levels.

Table 4 - Country-specific effect: robustness checks (1)

\begin{tabular}{|c|c|c|c|c|}
\hline Explained variable & \multicolumn{4}{|c|}{ In Imports ipct $_{\text {I }}$} \\
\hline Sample & $\begin{array}{c}(1) \\
\text { No Greater } \\
\text { China origins }\end{array}$ & $\begin{array}{c}\text { (2) } \\
\text { No countries } \\
\text { w/o retailers }\end{array}$ & $\begin{array}{c}\text { (3) } \\
\text { No cities } \\
\text { w/o retailers }\end{array}$ & $\begin{array}{c}\text { (4) } \\
\text { Processing } \\
\text { activities }\end{array}$ \\
\hline Western Retail Stores $_{i t} \times$ Retail $_{p}$ & $\begin{array}{c}0.157^{b} \\
(0.073)\end{array}$ & $\begin{array}{c}0.146^{b} \\
(0.073)\end{array}$ & $\begin{array}{c}0.057 \\
(0.123)\end{array}$ & $\begin{array}{c}0.068 \\
(0.059)\end{array}$ \\
\hline Western Retail Stores $_{i t} \times$ Retail $_{p} \times$ Home $_{c}$ & $\begin{array}{l}0.144^{b} \\
(0.069)\end{array}$ & $\begin{array}{l}0.151^{b} \\
(0.069)\end{array}$ & $\begin{array}{l}0.135^{b} \\
(0.068)\end{array}$ & $\begin{array}{l}-0.097 \\
(0.092)\end{array}$ \\
\hline Observations & $1,054,186$ & 999,702 & 800,185 & 363,602 \\
\hline R-squared & 0.825 & 0.822 & 0.842 & 0.844 \\
\hline City-Product-Country fixed effects & Yes & Yes & Yes & Yes \\
\hline Product-Country-Year fixed effects & Yes & Yes & Yes & Yes \\
\hline City-Country-Year fixed effects & Yes & Yes & Yes & Yes \\
\hline
\end{tabular}

Heteroskedasticity-robust standard errors clustered at the city level appear in parentheses. Imports ipct $_{\text {denotes }}$ imports of city $i$ from country $c$ in year $t$ for a product $p$. Products are defined as categories (non-retailer goods, retailer food goods and retailers non-food goods) within an HS2. Column 1 excludes imports flows from Hong-Kong, Taiwan and Macao. Column 2 excludes import flows from countries without global retail chains. Column 3 excludes cities without foreign (western and Asian) retailers. In contrast to our baseline regressions on ordinary trade transactions, in column 4 , imports correspond to processing activities. ${ }^{a},{ }^{b}$ and ${ }^{c}$ indicate significance at the $1 \%, 5 \%$ and $10 \%$ confidence levels. 
Table 5 - Country-specific effect: robustness checks (2)

\begin{tabular}{|c|c|c|c|c|}
\hline Explained variable & \multicolumn{4}{|c|}{ In Imports } \\
\hline Sample & $\begin{array}{c}\text { (1) } \\
\text { No Greater } \\
\text { China origins }\end{array}$ & $\begin{array}{l}\text { (2) } \\
\text { No countries } \\
\text { w/o retailers }\end{array}$ & $\begin{array}{c}\text { (3) } \\
\text { No cities } \\
\text { w/o retailers }\end{array}$ & $\begin{array}{c}\text { (4) } \\
\text { Processing } \\
\text { activities }\end{array}$ \\
\hline Western Retail Stores $_{i t} \times$ Retail $_{p}$ & $\begin{array}{c}0.173^{a} \\
(0.063)\end{array}$ & $\begin{array}{c}0.170^{a} \\
(0.065)\end{array}$ & $\begin{array}{c}0.085 \\
(0.100)\end{array}$ & $\begin{array}{c}0.073 \\
(0.063)\end{array}$ \\
\hline Western Retail Stores $_{i t} \times$ Retail $_{p} \times$ Home $_{c}$ & $\begin{array}{c}0.104 \\
(0.068)\end{array}$ & $\begin{array}{c}0.075 \\
(0.069)\end{array}$ & $\begin{array}{c}0.001 \\
(0.068)\end{array}$ & $\begin{array}{l}-0.104 \\
(0.099)\end{array}$ \\
\hline Western Retail Stores $_{i t} \times$ Food $_{p}$ & $\begin{array}{l}-0.086 \\
(0.130)\end{array}$ & $\begin{array}{l}-0.137 \\
(0.124)\end{array}$ & $\begin{array}{l}-0.163 \\
(0.210)\end{array}$ & $\begin{array}{l}-0.059 \\
(0.157)\end{array}$ \\
\hline Western Retail Stores $_{i t} \times$ Food $_{p} \times$ Home $_{c}$ & $\begin{array}{l}0.235^{c} \\
(0.130)\end{array}$ & $\begin{array}{l}0.268^{b} \\
(0.129)\end{array}$ & $\begin{array}{l}0.362^{b} \\
(0.169)\end{array}$ & $\begin{array}{c}0.078 \\
(0.428)\end{array}$ \\
\hline Observations & $1,054,186$ & 999,702 & 800,185 & 363,602 \\
\hline R-squared & 0.825 & 0.822 & 0.842 & 0.844 \\
\hline $\begin{array}{l}\text { City-Product-Country fixed effects } \\
\text { Product-Country-Year fixed effects } \\
\text { City-Country-Year fixed effects }\end{array}$ & $\begin{array}{l}\text { Yes } \\
\text { Yes } \\
\text { Yes }\end{array}$ & $\begin{array}{l}\text { Yes } \\
\text { Yes } \\
\text { Yes }\end{array}$ & $\begin{array}{l}\text { Yes } \\
\text { Yes } \\
\text { Yes }\end{array}$ & $\begin{array}{l}\text { Yes } \\
\text { Yes } \\
\text { Yes }\end{array}$ \\
\hline
\end{tabular}

Heteroskedasticity-robust standard errors clustered at the city level appear in parentheses. Imports $s_{i p c t}$ denotes imports of city $i$ from country $c$ in year $t$ for a product $p$. Products are defined as categories (non-retailer goods, retailer food goods and retailers non-food goods) within an HS2. Column 1 excludes imports flows from Hong-Kong, Taiwan and Macao. Column 2 excludes import flows from countries without global retail chains. Column 3 excludes cities without foreign retailers. In contrast to our baseline regressions on ordinary trade transactions, in column 4 , imports correspond to processing activities. ${ }^{a},{ }^{b}$ and ${ }^{c}$ indicate significance at the $1 \%, 5 \%$ and $10 \%$ confidence levels. 
Table 6 - Country-specific effect: robustness checks (3)

\begin{tabular}{|c|c|c|}
\hline \multirow[t]{2}{*}{ Explained variable } & \multicolumn{2}{|c|}{ In Imports ${ }_{i p c t}$} \\
\hline & $(1)$ & $(2)$ \\
\hline Western Retail Stores $_{i t} \times$ Retail $_{p}$ & $\begin{array}{l}0.123^{b} \\
(0.057)\end{array}$ & $\begin{array}{l}0.147^{b} \\
(0.057)\end{array}$ \\
\hline Western Retail Stores $_{i t} \times$ Retail $_{p} \times$ Home $_{c}$ & $\begin{array}{l}0.113^{c} \\
(0.065)\end{array}$ & $\begin{array}{c}0.075 \\
(0.067)\end{array}$ \\
\hline Western Retail Stores $_{i t} \times$ Food $_{p}$ & & $\begin{array}{l}-0.129 \\
(0.116)\end{array}$ \\
\hline Western Retail Stores $_{i t} \times$ Food $_{p} \times$ Home $_{c}$ & & $\begin{array}{l}0.217^{c} \\
(0.131)\end{array}$ \\
\hline Asian Retail Stores $_{i t} \times$ Retail $_{p}$ & $\begin{array}{l}0.160^{a} \\
(0.051)\end{array}$ & $\begin{array}{l}0.132^{b} \\
(0.055)\end{array}$ \\
\hline Asian Retail Stores $_{i t} \times$ Retail $_{p} \times$ Home $_{c}$ & $\begin{array}{c}0.039 \\
(0.080)\end{array}$ & $\begin{array}{c}0.099 \\
(0.097)\end{array}$ \\
\hline Asian Retail Stores $_{i t} \times$ Food $_{p}$ & & $\begin{array}{c}0.136 \\
(0.165)\end{array}$ \\
\hline Asian Retail Stores $_{i t} \times$ Food $_{p} \times$ Home $_{c}$ & & $\begin{array}{l}-0.263^{b} \\
(0.133)\end{array}$ \\
\hline Observations & $1,154,374$ & $1,154,374$ \\
\hline R-squared & 0.822 & 0.822 \\
\hline City-Product-Country fixed effects & Yes & Yes \\
\hline Product-Country-Year fixed effects & Yes & Yes \\
\hline City-Country-Year fixed effects & Yes & Yes \\
\hline
\end{tabular}

Heteroskedasticity-robust standard errors clustered at the city level appear in parentheses. Imports $i_{i p c t}$ denotes imports of city $i$ from country $c$ in year $t$ for a product $p$. Products are defined as categories (non-retailer goods, retailer food goods and retailers non-food goods) within an HS2. ${ }^{a},{ }^{b}$ and ${ }^{c}$ indicate significance at the $1 \%, 5 \%$ and $10 \%$ confidence levels. 
Table 7 - Country and company specific effect: retailer expansion and imports

\begin{tabular}{|c|c|c|c|c|}
\hline \multirow[t]{2}{*}{ Explained variable } & \multicolumn{4}{|c|}{ In Imports ipct $_{1}$} \\
\hline & $(1)$ & $(2)$ & (3) & $(4)$ \\
\hline Sample & All & $\begin{array}{c}\text { w/o } \\
\text { beverage }\end{array}$ & All & $\begin{array}{c}\text { w/o } \\
\text { beverage }\end{array}$ \\
\hline Carrefour-Auchan Stores $_{i t} \times$ Retail $_{p}$ & $\begin{array}{l}0.112^{c} \\
(0.060)\end{array}$ & $\begin{array}{l}0.155^{b} \\
(0.066)\end{array}$ & $\begin{array}{l}0.112^{c} \\
(0.060)\end{array}$ & $\begin{array}{l}0.155^{b} \\
(0.065)\end{array}$ \\
\hline Carrefour-Auchan Stores $_{i t} \times$ Food $_{p}$ & $\begin{array}{l}-0.072 \\
(0.077)\end{array}$ & $\begin{array}{l}-0.073 \\
(0.077)\end{array}$ & $\begin{array}{l}-0.095 \\
(0.091)\end{array}$ & $\begin{array}{l}-0.087 \\
(0.089)\end{array}$ \\
\hline Carrefour-Auchan Stores $_{i t} \times$ Retail $_{p} \times$ Home $_{c}$ & $\begin{array}{l}-0.023 \\
(0.113)\end{array}$ & $\begin{array}{l}-0.065 \\
(0.129)\end{array}$ & $\begin{array}{l}-0.024 \\
(0.114)\end{array}$ & $\begin{array}{l}-0.072 \\
(0.133)\end{array}$ \\
\hline Carrefour-Auchan Stores $_{i t} \times$ Food $_{p} \times$ Home $_{c}$ & $\begin{array}{l}0.388^{b} \\
(0.165)\end{array}$ & $\begin{array}{l}0.500^{a} \\
(0.181)\end{array}$ & $\begin{array}{l}0.757^{a} \\
(0.211)\end{array}$ & $\begin{array}{l}1.025^{a} \\
(0.212)\end{array}$ \\
\hline Tesco Stores $_{i t} \times$ Retail $_{p}$ & $\begin{array}{c}0.075 \\
(0.059)\end{array}$ & $\begin{array}{c}0.082 \\
(0.071)\end{array}$ & $\begin{array}{c}0.075 \\
(0.059)\end{array}$ & $\begin{array}{c}0.082 \\
(0.071)\end{array}$ \\
\hline Tesco Stores $_{i t} \times$ Food $_{p}$ & $\begin{array}{c}0.080 \\
(0.099)\end{array}$ & $\begin{array}{c}0.090 \\
(0.110)\end{array}$ & $\begin{array}{c}0.108 \\
(0.109)\end{array}$ & $\begin{array}{c}0.114 \\
(0.122)\end{array}$ \\
\hline Tesco Stores $_{i t} \times$ Retail $_{p} \times$ Home $_{c}$ & $\begin{array}{c}0.062 \\
(0.109)\end{array}$ & $\begin{array}{c}0.050 \\
(0.114)\end{array}$ & $\begin{array}{c}0.062 \\
(0.109)\end{array}$ & $\begin{array}{c}0.054 \\
(0.115)\end{array}$ \\
\hline Tesco Stores $_{i t} \times$ Food $_{p} \times$ Home $_{c}$ & $\begin{array}{c}0.941^{a} \\
(0.315)\end{array}$ & $\begin{array}{c}0.910^{a} \\
(0.322)\end{array}$ & $\begin{array}{c}1.156^{a} \\
(0.398)\end{array}$ & $\begin{array}{c}1.102^{a} \\
(0.420)\end{array}$ \\
\hline Metro Stores $_{i t} \times$ Retail $_{p}$ & $\begin{array}{c}0.098 \\
(0.100)\end{array}$ & $\begin{array}{c}0.083 \\
(0.109)\end{array}$ & $\begin{array}{c}0.099 \\
(0.100)\end{array}$ & $\begin{array}{c}0.084 \\
(0.108)\end{array}$ \\
\hline Metro Stores $_{i t} \times$ Food $_{p}$ & $\begin{array}{c}-0.074 \\
(0.167)\end{array}$ & $\begin{array}{c}-0.067 \\
(0.172)\end{array}$ & $\begin{array}{l}-0.048 \\
(0.172)\end{array}$ & $\begin{array}{c}-0.055 \\
(0.177)\end{array}$ \\
\hline Metro Stores $_{i t} \times$ Retail $_{p} \times$ Home $_{c}$ & $\begin{array}{c}0.074 \\
(0.123)\end{array}$ & $\begin{array}{c}0.081 \\
(0.134)\end{array}$ & $\begin{array}{c}0.074 \\
(0.123)\end{array}$ & $\begin{array}{c}0.084 \\
(0.134)\end{array}$ \\
\hline Metro Stores $_{i t} \times$ Food $_{p} \times$ Home $_{c}$ & $\begin{array}{l}-0.047 \\
(0.266)\end{array}$ & $\begin{array}{l}-0.045 \\
(0.280)\end{array}$ & $\begin{array}{c}0.065 \\
(0.265)\end{array}$ & $\begin{array}{c}0.081 \\
(0.287)\end{array}$ \\
\hline Walmart Stores $_{i t} \times$ Retail $_{p}$ & $\begin{array}{c}0.183^{a} \\
(0.053)\end{array}$ & $\begin{array}{c}0.210^{a} \\
(0.057)\end{array}$ & $\begin{array}{c}0.182^{a} \\
(0.052)\end{array}$ & $\begin{array}{c}0.208^{a} \\
(0.057)\end{array}$ \\
\hline Walmart Stores $_{i t} \times$ Food $_{p}$ & $\begin{array}{c}-0.041 \\
(0.157)\end{array}$ & $\begin{array}{l}-0.035 \\
(0.172)\end{array}$ & $\begin{array}{l}-0.079 \\
(0.175)\end{array}$ & $\begin{array}{l}-0.061 \\
(0.195)\end{array}$ \\
\hline Walmart Stores $_{i t} \times$ Retail $_{p} \times$ Home $_{c}$ & $\begin{array}{l}-0.116 \\
(0.085)\end{array}$ & $\begin{array}{l}-0.154^{c} \\
(0.089)\end{array}$ & $\begin{array}{l}-0.116 \\
(0.086)\end{array}$ & $\begin{array}{l}-0.152^{c} \\
(0.089)\end{array}$ \\
\hline Walmart Stores $_{i t} \times$ Food $_{p} \times$ Home $_{c}$ & $\begin{array}{c}0.083 \\
(0.141)\end{array}$ & $\begin{array}{c}0.066 \\
(0.156)\end{array}$ & $\begin{array}{c}0.044 \\
(0.142)\end{array}$ & $\begin{array}{c}0.013 \\
(0.166)\end{array}$ \\
\hline $\begin{array}{l}\text { Observations } \\
\text { R-squared }\end{array}$ & $\begin{array}{c}1,154,374 \\
0.791\end{array}$ & $\begin{array}{c}1,154,374 \\
0.822 \\
\end{array}$ & $\begin{array}{c}1,146,120 \\
0.791\end{array}$ & $\begin{array}{c}1,146,120 \\
0.823\end{array}$ \\
\hline Additional control variables & $\begin{array}{r}\text { Walmart R } \\
\text { Metro St }\end{array}$ & $\begin{array}{l}\text { efour-Aucha } \\
\text { Stores }_{i t} \times 1 \\
+\times \text { Home }_{c}\end{array}$ & $\begin{array}{l}\text { ores }_{i t} \times \mathrm{Ho} \\
{ }_{c} \text { Tesco St } \\
\text { n Retail Sto }\end{array}$ & $\begin{array}{l}\times \text { Home }_{c} \\
\times \text { Home }_{c}\end{array}$ \\
\hline City-Product-Country fixed effects & Yes & Yes & Yes & Yes \\
\hline Product-Country-Year fixed effects & Yes & Yes & Yes & Yes \\
\hline City-Year fixed effects & Yes & Yes & - & - \\
\hline City-Country-Year fixed effects & No & No & Yes & Yes \\
\hline
\end{tabular}

Heteroskedasticity-robust standard errors clustered at the city level appear in parentheses. Imports $s_{i p c t}$ denotes imports of city $i$ from country $c$ in year $t$ for a product $p$. Products are defined as categories (non-retailer goods, retailer food goods and retailers non-food goods) within an HS2. Column 2 and 4 excludes imports flows corresponding to the sector of beverage (chapter 22). ${ }^{a},{ }^{b}$ and ${ }^{c}$ indicate significance at the $1 \%, 5 \%$ and $10 \%$ confidence levels. 
Figure A-1 - Number of hypermarkets by the 5 leading international retailers in China, 1997 and 2012
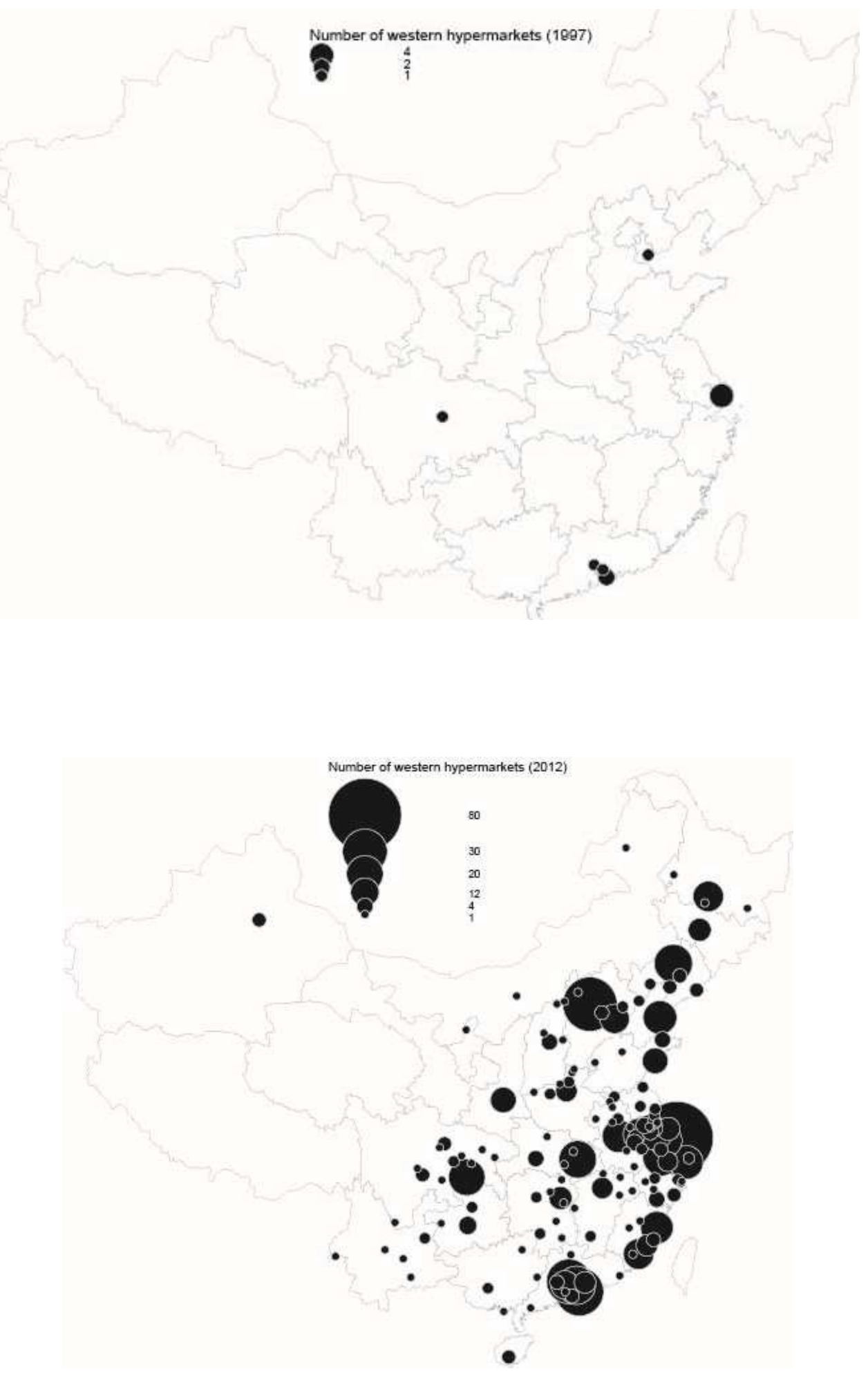

The number of hypermarkets is the total store count by location of the five western retailers (Auchan, Carrefour, Metro, Tesco and Walmart). 
Table A-1 - Data source of hypermarket locations

\begin{tabular}{||l|l||}
\hline \hline Retailer & Source \\
\hline Auchan & http://www.linkshop.com.cn/web/archives/2014/280981.shtml \\
Carrefour & http://www.carrefour.com.cn/Store/Store.aspx \\
Metro & http://www.metro.com.cn/public/home-cn/our_store \\
Tesco & http://www.cn.tesco.com/Stores_index.html \\
Walmart & http://www.wal-martchina.com/walmart/wminchina_map.htm \\
\hline \hline
\end{tabular}

Table A-2 - Information on western retail chains

\begin{tabular}{||l|c|cc|cc||}
\hline \hline $\begin{array}{l}\text { Western Hypermarket } \\
\text { chain }\end{array}$ & $\begin{array}{c}\text { Country of } \\
\text { origin }\end{array}$ & $\begin{array}{c}\text { Year } \\
\text { of entry }\end{array}$ & $\begin{array}{c}\text { Location } \\
\text { of entry }\end{array}$ & $\begin{array}{c}\text { Market share } \\
\text { in } 2010\end{array}$ & $\begin{array}{c}\text { Number of } \\
\text { Hypermarkets in 2012 }\end{array}$ \\
\hline Auchan & France & 1999 & Shanghai & $13.3 \%$ & 56 \\
Carrefour & France & 1995 & Beijing & $10.4 \%$ & 226 \\
Metro & Germany & 1996 & Shanghai & $3.4 \%$ & 64 \\
Tesco & UK & 1998 & Shanghai & $3.4 \%$ & 111 \\
Walmart & USA & 1996 & Shenzhen & $10.4 \%$ & 401 \\
\hline \hline
\end{tabular}

Market shares in 2010 are computed using information on grocery sales from Planet retail.

Table A-3 - Summary statistics

\begin{tabular}{||l|c|c|ccccc||}
\hline \hline Variable & year & null value & \multicolumn{5}{|c|}{ Positive value } \\
Obs & Obs & Mean & Std. Dev. & Min & Max \\
\hline Western Retail Stores $_{i t}$ & 1997 & 260 & 7 & 1.57 & 1.13 & 1 & 4 \\
Western Retail Stores $_{i t}$ & 2012 & 135 & 149 & 5.51 & 9.57 & 1 & 80 \\
\hline Imports $_{i p c t}$ & 1997 & 0 & 267 & 111 & 461 & 0.001 & 6360 \\
Imports $_{i p c t}$ & 2012 & 0 & 284 & 2390 & 7220 & 0.037 & 71300 \\
\hline \hline
\end{tabular}

Imports $_{i p c t}$ denotes imports of city $i$ from country $c$ in year $t$ for a product $p$, in million USD. 